The Effects of Progesterone and Estrogen Hormone Levels on Some Reproductive Characteristics of The Akkaraman Sheep

\author{
Afşin KOCAKAYA ${ }^{1}$, Ceyhan ÖZBEYAZ2 \\ Department of Animal Science, Faculty of Veterinary Medicine, Ankara University, Ankara, Turkey \\ ${ }^{1}$ https://orcid.org/0000-0003-2023-8895, $2^{1}$ https://orcid.org/0000-0002-3748-9992 \\ $\square$ : akocakaya@ankara.edu.tr
}

\begin{abstract}
In this study, progesterone and estrogen hormone levels of Akkaraman (White Karaman/WK) sheep and their effects on some reproductive traits were investigated. The data obtained, from 31 ewes, as $90.32 \%$ for lambing, $53.57 \%$ for a single birth, $46.42 \%$ for twinning, $132.25 \%$ for lamb production and 1.46 for litter size. Between the first and second estrus, progesterone levels were found to be between $3.69-12.20 \mathrm{ng} / \mathrm{ml}$ for singles and 3.04-10.44 ng/ml for twins; estrogen levels were determined to be between 39.40-84.03 $\mathrm{pg} / \mathrm{ml}$ for singles and 52.44-72.77 $\mathrm{pg} \mathrm{ml}$ for twins. The equivalent values at anestrus period of progesterone were $0.20-10.20 \mathrm{ng} / \mathrm{ml}$, and estrogen levels were $6.30-169.60 \mathrm{pg} / \mathrm{ml}$. The effects of birth type on estrogen level were not-significant, while progesterone levels were determined to be significant on the second and third days before the second estrus $(\mathrm{P}<0.05$ and $\mathrm{P}<0.001)$. In conclusion, least square means and standard errors and differences between maximum and minimum progesterone hormone levels were similar to those of prolific breeds. Estrogen levels were found lower than prolific breeds but were higher than non-prolific breeds. Therefore, Akkaraman breed can be foreseen as a combine prolific breed.
\end{abstract}

\title{
Akkaraman Koyunlarının Bazı Üreme Özellikleri Üzerine Progesteron ve Östrojen Hormon Seviyelerinin Etkileri
}

\section{ÖZET}

$\mathrm{Bu}$ çalışmada, Akkaraman koyunlarının üreme döneminde progesteron ve östrojen hormon düzeylerini ve bu hormonların bazı üreme özellikleri üzerine etkileri incelenmiştir. İncelenen 31 baş koyunda doğum oranı \%90.32; tek doğum oranı \%53.57; ikizlik oranı \%46.42; kuzu verimi \%132.25 ve tek doğuma kuzu oranı ise 1.46 olmuştur. Birinci ikinci östrus arası progesteron seviyeleri tek doğuran koyunlarda 3.69-12.20 ng/ml; ikiz doğuran koyunlarda 3.04$10.44 \mathrm{ng} / \mathrm{ml}$; östrojen miktarları tek doğuran koyunlarda 39.40-84.03 $\mathrm{pg} / \mathrm{ml}$ ve ikiz doğuran koyunlarda 52.44-72.77 pg/ml olarak bulunmuştur. Progesteronun anöstrus dönemindeki seviyesi 0.20 $10.20 \mathrm{ng} / \mathrm{ml}$; östrojenin $6.30-169.60 \mathrm{pg} / \mathrm{ml}$ olmuştur. Östrojen hormonunun doğum tipi üzerine etkisi önemsiz; progesteron seviyelerinin ikinci östrustan önceki ikinci ve üçüncü günlerde doğum tipine etkisinin önemli olduğu $(\mathrm{P}<0.05$ ve $\mathrm{P}<0.001)$ tespit edilmiştir. Sonuç olarak, progesteron hormonunun ortalama değerleri ile maksimum ve minimum değerleri arasındaki farklılık prolifik ırklara benzerlik göstermektedir. Östrojen hormonu seviyeleri prolifik ırklardan düşük, prolifik olmayan ırklardan yüksek olmuştur. Bu nedenle Akkaraman ırkının kombine verimli prolifik bir ırk olarak değerlendirilebileceği düşünülmektedir.

To Cite : Kocakaya A, Özbeyaz C 2019. The Effects of Progesterone and Estrogen Hormone Levels on Some Reproductive Characteristics of The Akkaraman Sheep. KSU J. Agric Nat. 22(Suppl 2): 424-430. DOI: 10.18016/ ksutarimdoga.vi.583400. 


\section{INTRODUCTION}

Sheep breeding is an important production field and common in many countries, which have arid climate conditions and wide pastures. With the advantage of characteristic traits of species, sheep breeding is highly profitable in low-quality pastures. Sheep is livestock with good adaptability, easy handling, and low costs. Moreover, sheep can provide most of its nutritional needs from pasture (Akçapınar, 2000).

Although sheep breeding has an important place in Turkey's livestock sector, a vast majority of the sheep breeds are native breeds with a low efficiency like WK. It is important for Turkey to conduct some research to improve the yields of these native breeds, and develop new genotypes with high efficiency and to ensure sustainable small ruminant production (Atasoy et al.,2003; Ünal et al., 2003; Ünal et al., 2004).

WK sheep is a multipurpose, fat-tailed, indigenous breed growing in the semi-arid continental climate conditions in Central Anatolia. The purpose of this study was to determine the levels of the progesterone and estrogen hormones along with the natural estrous cycle and investigate the relationship between reproductive characteristics and steroid hormones (progesterone and estrogen) of the WK sheep.

\section{MATERIALS AND METHODS}

The research approved by Ankara University Animal Experiments Local Ethics Committee (dated 11/04/2012, decree number 2012-8-54).

\section{Animals and experimental design}

This research was conducted in 2012-2013 at the Gözlü State Farm (38 $\left.29^{\prime} \mathrm{N}-32^{\circ} 27^{\prime} \mathrm{E}\right)$ in Turkey. Thirtyone WK ewes in heat with different ages $(2 ; 3 ; 4$ and 5$)$ were selected from the elite flocks by using teaser rams, and they did not mate until the second estrus. The ewes were selected in three days at the beginning of the mating season. All of the ewes were monitored by rams twice a day for 12 days from the first estrus, and they mated when in heat. The blood samples were collected daily from the first estrus to the fifth day after the second estrus. The blood samples $(10 \mathrm{ml})$ were taken twice again from the same ewes in the $4^{\text {th }}$ month of lactation which is an anestrus period.

\section{Sampling and obtaining data}

Total of 629 X $10 \mathrm{ml}(6.290 \mathrm{ml})$ blood samples were taken from the jugular vein into tubes and the samples were centrifuged at $3000 \mathrm{rpm}$ for 10 minutes to the obtained serum (Bartlewski et al., 1998). The samples were stored at $-80^{\circ} \mathrm{C}$ until the analysis of the progesterone and estrogen hormone levels (Tworoger et al., 2006).

The time between the 1st and the 2nd estrus calculated as the estrus cycle length. The birth of sheep was monitored and the days between the conception and the birth were calculated as the gestation period (Ünal and Akçapınar, 1994; Ünal et al., 2006a). The lambing rate, fertility, single and twin birth rates and the litter size of the ewes were determined. The progesterone and estrogen levels of the serum were determined by Enzyme-Linked Immunosorbent Assay (ELISA) (Ali et al., 2006; Haliloğlu and Serpek, 2000; Sulu et al., 1988).

\section{Statistical Analysis}

The obtained data were compared by birth type groups. The t-test was used to analyse the data of the progesterone and the estrogen levels (STATA 12/MP4).

\section{RESULTS}

\section{Reproductive Characteristics}

At the lambing season, 28 ewes gave birth, and three ewes remained infertile. The means for reproductive traits were obtained as $90.32 \%$ for the lambing rate, $53.57 \%$ for the single birth rate, $46.42 \%$ for the twinning rate, $132.25 \%$ for the lamb production and 1.46 for the litter size. The average gestation period by the type of birth was determined as $149.92 \pm 0.43$ days for the single lambing ewes and $150.63 \pm 0.24$ days for the twin lambing ewes. Similarly, the average estrous cycle duration by birth type was determined as $14.57 \pm 0.35$ for the single lambing ewes and $16.00 \pm 0.33$ for the twin lambing ewes.

\section{Progesterone and Estrogen Hormone Levels}

The progesterone and estrogen levels of the WK ewes were analysed during the estrus and anestrus period by type of the birth.

As a result of the ELISA tests, the hormone levels of progesterone and oestrogen could not be determined on some days. This situation could have resulted from the problems in the samples. For this reason, there were differences in the numbers of the animals according to the sample collection days.

The progesterone hormone levels according to the type of birth on the six-day period before the second estrus and the importance of the controls between the groups are given in Table 1. During all examination days, except for the 6th day before the second estrus, the levels of the progesterone of the single lambing ewes were found higher than the twin lambing ewes. However, the differences between the levels of the progesterone on the days second and $3^{\text {rd }}$ before the second estrus were found statistically significant $(\mathrm{P}<0.05 ; \mathrm{P}<0.001)$. The levels of progesterone were higher in the single lambing ewes than those of the twin lambing ewes on the 2 nd and third days before the second estrus.

The estrogen hormone levels of ewes were determined in 11 days (six days before the second estrus, on the 
day of second estrus and four days after the second estrus). As a result of the analyses, it was found that the effect of type of birth on the levels of estrogen was significant $(\mathrm{P}<0.05)$ on the 4 th day after the second estrus, but was not significant on all other days. The statistics for estrogen hormone were given in Tables 2 and 3 , respectively. The amount of the estrogen does not follow a regular pattern by type of birth.
Assuming that sheep in lactation was in anestrus, the research material for the hormone analysis of the anestrus period was sampled twice in a total of 27 heads in 24 hours in June 2013. The hormone levels of the progesterone and estrogen were detected to be between $0.20-10.20 \mathrm{ng} / \mathrm{ml}$ and $6.30-239.60 \mathrm{pg} / \mathrm{ml}$, respectively.

Table 1. Average progesterone levels \pm standard error in the days before the second oestrus by birth type (ng ml)

\begin{tabular}{|c|c|c|c|c|c|c|c|c|c|c|c|c|}
\hline \multirow{3}{*}{ Birth Type } & \multicolumn{12}{|c|}{ Days $^{a}$} \\
\hline & \multicolumn{2}{|c|}{-6} & \multicolumn{2}{|l|}{-5} & \multicolumn{2}{|c|}{-4} & \multicolumn{2}{|l|}{-3} & \multicolumn{2}{|l|}{-2} & \multicolumn{2}{|l|}{-1} \\
\hline & $\mathrm{n}$ & & $\mathrm{n}$ & & $\mathrm{n}$ & & $\mathrm{n}$ & & $\mathrm{n}$ & & $\mathrm{n}$ & \\
\hline Single ${ }^{b}$ & 15 & $7.80 \pm 1.71$ & 12 & $11.18 \pm 2.76$ & 13 & $11.53 \pm 2.85$ & 15 & $12.20 \pm 2.72$ & 15 & $8.92 \pm 2.50$ & 15 & $3.69 \pm 1.31$ \\
\hline Twin $^{c}$ & 11 & $9.96 \pm 2.69$ & 12 & $10.44 \pm 2.81$ & 12 & $10.00 \pm 2.22$ & 12 & $6.80 \pm 1.45$ & 12 & $2.60 \pm 0.67$ & 12 & $3.04 \pm 1.99$ \\
\hline $\mathrm{P}$ & & - & & - & & - & & $*$ & & $* * *$ & & - \\
\hline
\end{tabular}

a Six days period before the second oestrus.; b Single lambing ewes.; c Twin lambing ewes.

Table 2. Average Oestrogen levels \pm standard error in the days before the second oestrus by birth type (pg $\mathrm{ml})$

\begin{tabular}{|c|c|c|c|c|c|c|c|c|c|c|c|c|}
\hline \multirow{5}{*}{$\begin{array}{l}\text { Birth } \\
\text { Type } \\
\text { Single } \\
\text { b }\end{array}$} & \multicolumn{12}{|c|}{ Days $^{\mathrm{a}}$} \\
\hline & -6 & & -5 & & -4 & & -3 & & -2 & & -1 & \\
\hline & $\mathrm{n}$ & & $\mathrm{n}$ & & $\mathrm{n}$ & & $\mathrm{n}$ & & $\mathrm{n}$ & & $\mathrm{n}$ & \\
\hline & & $43.98 \pm 17.6$ & 1 & $84.03 \pm 26.9$ & 1 & $83.47 \pm 20.7$ & 1 & $78.54 \pm 24.7$ & 1 & $79.33 \pm 37.9$ & 1 & $39.40 \pm 10.8$ \\
\hline & 0 & 9 & 4 & 2 & 4 & 8 & 5 & 7 & 2 & 1 & 4 & 2 \\
\hline Twin $^{c}$ & 6 & $\begin{array}{l}62.95 \pm 32.2 \\
0\end{array}$ & $\begin{array}{l}1 \\
3 \\
\end{array}$ & $\begin{array}{l}72.68 \pm 32.1 \\
1\end{array}$ & $\begin{array}{l}1 \\
1\end{array}$ & $\begin{array}{l}72.77 \pm 33.7 \\
7\end{array}$ & $\begin{array}{l}1 \\
2\end{array}$ & $\begin{array}{l}52.44 \pm 15.8 \\
6\end{array}$ & $\begin{array}{l}1 \\
2\end{array}$ & $\begin{array}{l}54.17 \pm 23.0 \\
0\end{array}$ & $\begin{array}{l}1 \\
1\end{array}$ & $\begin{array}{l}56.54 \pm 29.8 \\
1\end{array}$ \\
\hline
\end{tabular}

a Six days period before the second oestrus.; b Single lambing ewes.; c Twin lambing ewes.

Table 3. Average Oestrogen levels \pm standard error on the second oestrus and four days after the second oestrus by birth type (ng ml)

\begin{tabular}{|c|c|c|c|c|c|c|c|c|c|c|}
\hline \multirow{3}{*}{ Birth Type } & \multicolumn{10}{|c|}{ Days $^{a}$} \\
\hline & \multicolumn{2}{|c|}{$2^{\text {nd }}$ Oestrus } & \multicolumn{2}{|l|}{1} & \multicolumn{2}{|l|}{2} & \multicolumn{2}{|l|}{3} & \multicolumn{2}{|l|}{4} \\
\hline & $\mathrm{n}$ & & $\mathrm{n}$ & & $\mathrm{n}$ & & $\mathrm{n}$ & & $\mathrm{n}$ & \\
\hline Single $^{b}$ & 15 & $69.33 \pm 31.60$ & 14 & $46.12 \pm 17.98$ & 14 & $58.50 \pm 23.00$ & 12 & $50.34 \pm 17.47$ & 12 & $81.47 \pm 35.27^{\mathrm{A}}$ \\
\hline Twin $^{c}$ & 10 & $97.57 \pm 47.66$ & 11 & $68.72 \pm 36.21$ & 13 & $56.27 \pm 33.17$ & 11 & $65.54 \pm 28.98$ & 8 & $38.66 \pm 8.39^{\mathrm{B}}$ \\
\hline $\mathrm{P}$ & & - & & - & & - & & - & & $*$ \\
\hline
\end{tabular}

a Second oestrus day and four days period after the second oestrus.; b Single lambing ewes.; c Twin lambing ewes.

\section{DISCUSSION}

\section{Reproductive Characteristics}

The average gestation periods for this study were $149.92 \pm 0.43$ for the single lambing ewes and $150.63 \pm 0.24$ days for the twin lambing ewes. These values were close to the gestational periods that were reported before for the WK sheep (Akçapinar and Kadak, 1982; Ünal et al., 2006a), similar to the values determined for the WK crossbreeds (Ünal et al., 2006a) as between 144-152 days (Akçapınar, 2000) which were reported for sheep breeds. The effect of birth type on gestation period was found non-significant. This situation does not overlap with a prior report that mentions the increasing the number of offspring that leads to a decrease in the duration of the gestation period (Güler, 2007); this could be due to the numbers of animals in the groups.

The average estrus cycle lengths were determined as
$14.57 \pm 0.35$ days for the single lambing ewes and $16.00 \pm 0.33$ days for the twin lambing ewes. While these values were lower than previous ones for the WK and its crossbreeds (Ünal et al., 2006a). They were also among the values that were reported for the sheep species which are 14-19 days (Akçapınar, 2000).

In this study, the estrus cycle lengths, which varied between 13-18 days, were shorter than those of given for Bafra sheep (15-21 days) (Özarslan, 2014). This situation may be related to the insufficient luteinisation and the shorter lifespan of Corpus Luteum (CL) (Bartlewski et al., 2011). Similar to the earlier reports, the effect of birth type on the estrus cycle was not significant (Özarslan, 2014). A previous study showed that there was a negative correlation between the cycle length and litter size (Özarslan, 2014). In this study, despite the estrus cycle being not affected by birth type, the lengths of the estrus cycle of 
the twin lambing ewes were longer than those of the single lambing ewes. It indicates that the single and multiple births were occurring independently of the estrous cycle length.

The determination of the gestation period and estrous cycle length according to breeds would be useful for some management applications in sheep breeding such as the determining the mating time, practising of flushing, detection of the second mating time, the timing of gestation applications, and determination of the lambing season in the flock.

The results of this study showed that the birth rate (90.32\%) was higher than the earlier studies of theWK sheep (Akçapinar et al., 1982; Ünal et al., 2006a; Yakan et al., 2012), and it was lower than the value reported by Akçapınar et al., (Akçapınar et al., 2000). Moreover, it is among the values that were reported in some studies (Çolakoğlu and Özbeyaz, 1999; Tekerli et al., 2002). Lamb production (132.25\%), which was the most critical reproductive output, was higher than the values in the earlier results (Akçapinar et al., 1982; Çolakoğlu and Özbeyaz, 1999; Yakan et al., 2012) and simlar to Büyüktekin and Öztürk (2018)'s findings. The single birth rate $(53.57 \%)$ was lower than the values reported in other studies (Akçapınar et al., 2000; Tekerli et al., 2002; Yakan et al., 2012). The twinning rate $(46.42 \%)$ was similar to the earlier results (Çolakoğlu and Özbeyaz, 1999), and it was higher than the values reported in some studies (Tekerli et al., 2002; Yakan et al., 2012). Also, it was higher than the general values for WK and its crossbreeds reported by Akçapınar et al., (2000). The litter size (1.46) was higher than the values of the various studies for WK and its crossbreeds (Akçapınar et al., 1982; Akçapınar et al., 2000; Tekerli et al., 2002; Ünal et al., 2006b; Yakan et al., 2012). Furthermore, it was similar to the earlier reports (Çolakoğlu and Özbeyaz, 1999) and lower than the values reported for the WK crossbreeds (Ünal et al., 2006b).

The lamb production, twinning rate and litter size in this study were found higher than other studies. This situation would be as a result of the animal material of this study, which was selected from the elite flock at the Gözlü state farm.

\section{Progesterone Levels}

The mean progesterone levels on the six-day period before the second oestrus were analyzed by the birth type groups. The levels of progesterone were significantly higher in the single lambing ewes than twin lambing ewes on the 2nd and third days, before the second oestrus. This was opposite to Haliloglu and Serpek, (2000)'s findings for the Merino sheep. However, Canoğlu and Sarıbay, (2012) reported that the high progesterone levels suppress the growth of seconder and graafian follicles. As a consequence, in this study, a high level of progesterone was required for the low amount of ovum development. Also, Bartlewski et al., (2017) reported that the progesterone injections decreased the ovulation rate in prolific ewes.

According to Goodman and Inskeep, (2015), the ovulatory follicles of the twin ovulations need more days for maturing than the single ovulations and twin ovulations occurring due to the reducing of the atresia of smaller and larger follicles. This situation was related to the penultimate and last follicular development. While the large follicles developing on the penultimate wave were retained, the small follicles on the last wave reach the ovulatory size and competence. Then both were ovulated. More follicles ovulated from the penultimate wave in the ewes with lower progesterone levels. Bartlewski et al., (2011) reported that the high ovulation rate in some prolific breeds might be related to follicles in the last two follicular waves, and that prolific breeds had lower progesterone levels than non-prolific breeds. Moreover, the prolific breeds have more but a smaller CL. Likewise, Johnson et al., (1996) found that the lower levels of progesterone increased the ovulation rate.

The rate of ovulation was affected by hormonal, genetic and environmental factors. The most critical hormonal effect on the ovulation rate is progesterone; lower progesterone levels increase the ovulation rate independent of nutritional management (Goodman and Inskeep, 2015). In some studies which were investigated, the lower progesterone effects on the ovulation rate reported that lower progesterone levels increased the ovulation rate (Johnson et al., 1996) and the prolific breeds had lower progesterone levels compared to the non-prolific breeds (Bartlewski et al., 1999). Another study reported that the lower progesterone levels resulted in more ovulation by ensuring the continuity of the previous follicles, but increasing the ovulation rates did not lead to an increase in the number of lambs. In the same study, it was reported that oocytes from the penultimate wave were old and they had an inability for the fertilization or an embryonic development like cattle. Additionally, it was reported that the litter size could be limited with the uterus capacity (Devonish et al., 2009). However, in this study, the twin lambing ewes have lower progesterone levels, and the difference between the progesterone levels was found statistically significant on $2^{\text {nd }}$ and third days before the second estrus $(\mathrm{P}<0.05$, $\mathrm{P}<0.001)$. Because the WK breed was medium-sized and also slightly bigger than medium-sized breeds, it was considered that there will not be a problem with the uterine capacity. Eventually, this kind of problem did not occur in this study.

The progesterone levels during the period that starts six days before the second estrus ranged between 2.60$12.20 \mathrm{ng} / \mathrm{ml}$ and during the estrous cycle between $0.20^{-}$ $39.50 \mathrm{ng} / \mathrm{ml}$. Values in this study were higher than the progesterone levels determined before as $0.10-2.00$ 
ng/ml by Karagül et al., (1999) and similar with the progesterone levels determined before as 0.02-6.17 $\mathrm{ng} / \mathrm{ml}$ by Arsoy and Sağmanligil (2018) for the WK sheep and various studies (Ali et al., 2006; Ali and Hayder, 2008; Coelho et al., 2006; Cunningham et al., 1975; Haliloğlu and Serpek, 2000; Seekallu et al., 2010) that were conducted on non-prolific breeds. They found similar mean progesterone levels reported in various studies (Mitchell et al., 1999; Özarslan, 2014; Sulu et al., 1988) on prolific breeds.

Goodman and Inskeep, (2015) reported that fluctuations in progesterone hormone levels in the estrus cycle did not change between breeds, but the maximum progesterone levels can be changed. Accordingly, it was considered that the high progesterone levels determined in this study could be specific for the WK breed.

The average amount of progesterone determined in the present study was higher than the reported values of $0.10-2.00 \mathrm{ng} / \mathrm{ml}$ for WK determined by Karagül et al., (1999). It could be because of the difference in the origins of animals, numbers of animals and trial procedures.

In summary, the mean levels and the differences between the minimum and maximum values of the progesterone levels were similar to the prolific breeds. Also, the mean levels of progesterone were higher than those of the non-prolific breeds.

\section{Estrogen Levels}

For the estrogen level analyses, blood samples were collected six days before the second estrus, on the day of the second estrus and four days after the second estrus. As a result of the analyses, the effect of type of birth on the estrogen levels was significant only on the $4^{\text {th }}$ day after the second estrus.

The oestrogen levels showed a certain fluctuation on the days when it was measured (Goodman and Inskeep, 2015). The level of estrogen fell on the day before the second estrus and peaked on the day of the second estrus and then began to decrease. With that, on the $2^{\text {nd }}$ day after the second estrus, estrogen started to rise again (Özarslan, 2014).

During the test days, the estrogen levels varied between $38.66-97.57 \mathrm{pg} / \mathrm{ml}$. These values were found out to be close to the mean values $(20.00-60.00 \mathrm{pg} \mathrm{ml})$ that were determined by Karagül et al., (1999) and higher than the estrogen levels determined before as 3.50-8.42 pg/ml by Arsoy and Sağmanlıgil (2018) for WK sheep, higher than the estrogen levels reported in various studies (Bartlewski et al., 1999; Haliloğlu and Serpek, 2000; Seekallu et al., 2010) and lower than the mean estrogen levels reported for Bafra sheep (Özarslan, 2014).

Johnson et al., (1996) reported that the ewes with high levels of estrogen before mating failed to conceive compared to the ewes with low concentrations of estrogen. It could be due to the effect of the high levels of estrogen on the oocyte development in all preovulatory follicles or alter function in the oviduct and uterus. In the present study, on the six-day period before the second estrus progesterone and estrogen levels were higher in the single lambing ewes than in the twin lambing ewes.

This study indicates that the lower progesterone levels are necessary to increase the ovulation rates and low levels of progesterone with lower estrogen levels are essential for increasing the number of lambs.

\section{Progesterone and Estrogen Levels during Anestrus}

The mean levels of progesterone and estrogen were detected as $1.60 \mathrm{ng} / \mathrm{ml}$ and $45.14 \mathrm{pg} / \mathrm{ml}$, respectively in the samples taken twice at a 24 -hour interval during the anestrus period. When these values were compared to those of estrus period, the mean level of the anoestrus progesterone was lower than the estrus levels, and the estrogen level was similar to the oestrus levels.

The mean levels of progesterone in the anoestrus period were lower than the mean levels for WesternWhite Faced sheep (Bartlewski et al., 1998) and Santa Inês sheep (Coelho et al., 2006). Those were between the levels of progesterone detected in autumn, winter and spring for Ossimi sheep (Ali et al., 2006) and these were similar to the Bafra sheep anestrous progesterone levels (Özarslan, 2014).

While the level of oestrogen in the anestrus period was higher than Western-White Faced sheep (Bartlewski et al., 1998), it was similar to levels of Bafra sheep (Özarslan, 2014).

In this study, some sheep in the anestrus period have similar levels of hormones in the oestrus period and have similar levels of hormones with prolific Bafra sheep which was known to show estrus throughout a year. It suggests that the Akkaraman sheep could show estrus during a year.

To conclude, the estrus cycle length and the gestation period for the single lambing ewes were determined to be $14.57 \pm 0.35$ and $149.92 \pm 0.43$ days, respectively. Similarly, the estrus cycle length and the gestation period for the twin lambing ewes were determined to be $16.00 \pm 0.33$ and $150.63 \pm 0.24$ days, respectively. This data would be useful for the management practices in sheep breeding.

The reproductive hormone levels were determined in this study and the effect of birth type on estrogen (except the 4 th day after the second estrus) was not found significant $(\mathrm{P}>0.05)$. It is important that the difference between the minimum and maximum values of progesterone was higher than those of non-prolific breeds in general, similar to the values reported in the prolific breeds, and that the levels of estrogen are lower 
but more similar to the prolific breeds. This situation indicates that the WK breed needs to be investigated for prolificacy.

The levels of progesterone were higher in the single lambing ewes ascompared to the twin lambing ewes, and were found statistically significant on second and third days before the second estrus $(\mathrm{P}<0.05, \mathrm{P}<0.001)$. It suggests that there would be a negative relationship between the levels of progesterone and the twinning rate.

The similarity between the anoestrous and estrous progesterone levels and the resemblance of the progesterone levels with yearlong to polyoestrous breeds was an essential finding of the present study. This situation indicates that the ability of the WK breed to show estrus in the anoestrus period should be investigated. It is essential to study the ability of the breed to show estrus through the year under natural conditions and to examine the possibility of three lambing in two years.

In conclusion, this study indicates that the low progesterone levels with the low oestrogen levels on oestrus cycle result with multiple births. It could be used in selection for increasing twin births. Additionally, the Akkaraman sheep could be utilised as a prolific breed.

\section{ACKNOWLEDGEMENTS}

This article was produced from the $\mathrm{PhD}$ thesis of the first author with the consultancy of the second author and the study was supported by the Scientific and Technological Research Council of Turkey-TUBITAK (project number: 1120342). An oral presentation produced from the same thesis tittled "Investigation of Some Reproductive Characteristics and Progesterone Levels of Akkaraman Sheep" was presented at the International Congress on Advances in Veterinary Sciences \& Technics (ICAVST) in Bosnia and Herzegovina and printed as full text in Book of Abstracts p:218-224, 24-29th August 2016.

\section{REFERENCES}

Akçapınar H 2000. Koyun Yetiştiriciliği 2. Baskı, ISBN: 975-96978-1-5, TR: İsmat matbaası.

Akçapinar H, Kadak R 1982. The effects of some factors on the duration of pregnancy and birth weight in Akkaraman and Morkaraman sheep breeds. Vet J Ankara Univ 29: 392-400.

Akçapınar H, Kadak R, Odabaşioğlu F 1982. Comparative investigations on fertility and milk yield of Morkaraman and Kangal-Akkaraman sheep, Vet J Ankara Univ 29: 379-391.

Akçapınar H, Özbeyaz C, Ünal N, Avci M 2000. the possibilities of developing dam and sire lines using Akkaraman, Sakız and Kıvırcık sheep breeds for lamb production I. Fertility in Akkaraman sheep, survival rate and growth characteristics of Sakız x Akkaraman $\mathrm{F}_{1}$ and Kivırcık $\mathrm{x}$ Akkaraman $\mathrm{F}_{1}$ Lambs, Turk J Vet Anim Sci 24: 71-79.

Atasoy F, Ünal N, Akçapinar H, Mundan D 2003. Some production traits of Karayaka and Bafra (Chios $\mathrm{x}$ Karayaka $B_{1}$ ) sheep. Turk J Vet Anim Sci 27: 259264.

Ali A, Derar R, Hussein H 2006. Seasonal variation of the ovarian follicular dynamics and luteal functions of sheep in the subtropics. Theriogenology 66: 463469.

Ali A, Hayder M 2008. Seasonal variation of reproductive performance, foetal development and progesterone concentrations of sheep in the subtropics. Reprod Domest Anim 43: 730-734.

Arsoy D, Sağmanlıgil V 2018. Reproductive cycles in white Karaman ewes: comparison of ovarian hormone secretion and reproductive behavior in non-pregnant and pregnant ewes in semi-intensive conditions. Acta Scientiarum 10.4025/ actascianimsci.v40i1.39908.

Bartlewski PM Beard AP, Cook SJ, Rawlings NC 1998. Ovarian follicular dynamics during anoestrus in ewes. J Reprod Fertil 113: 275-285.

Bartlewski PM, Baby TE, Giffin JL 2011. Reproductive cycles in sheep. Anim Reprod Sci 124: 259-268.

Bartlewski PM, Beard AP, Cook SJ, Chandolia RK, Honaramooz A, Rawlings NC 1999. Ovarian antral follicular dynamics and their relationships with endocrine variables throughout the oestrous cycle in breeds of sheep differing in prolificacy. J Reprod Fertil 115: 11-124.

Bartlewski PM, Sohal J, Paravinja V, Baby T, Oliveira MEF, Murawski M, Schwarz T, Zieba DA, Keisler DH 2017. Is progesterone the key regulatory factor behind ovulation rate in sheep? Domest Anim Endocrin 58: 30-38.

Büyüktekin M, Öztürk A 2018. Effects of some factors on reproduction perfoemance of Akkaraman sheep in breeder flocks in Konya province, Turkey. Selcuk J Agr Food Sci, 31 (1): 87-90.

Canoğlu E, Saribay K 2012. Üreme kanalı morfolojisi ve üreme fizyolojisi. (Çiftlik Hayvanlarında Doğum ve Jinekoloji TR: Medipres: Ed. Semecan A, Kaymaz M, Fındık M, Rişvanlı A, Köker A) 521-548.

Coelho LA, Rodrigues PA, Nonaka KO, Sasa A, Balieiro JCC, Vincente WRR, Cipolla-Neto J 2006. Annual pattern of plasma melatonin and progesterone concentrations in hair and wool ewe lambs kept under natural photoperiod at lower latitudes in the southern hemisphere. J Pineal Res 41: 101-107.

Cunningham NF, Symons AM, Saba N 1975. Levels of progesterone, LH and FSH in the plasma of sheep during the oestrous cycle. J Reprod Fertil 45: 177180.

Çolakoğlu N, Özbeyaz C 1999. Comparison of Some Production Traits in Malya and Akkaraman Sheep. 
Turk J Vet Anim Sci 23: 351-360.

Devonish EH, Knights M, Inskeep EK 2009. Effect of expected peripheral concentrations of progesterone on ovulation rate and litter size in Barbados blackbelly ewes. Sheep goat res. j. 24: 17-25.

Goodman RL, Inskeep EK 2015. Control of the ovarian cycle of the sheep. (Knobil and Neill's Physiology of Reproduction Fourth Edition Volume 2. London, UK: Elsevier: Ed. Plant TM, Zelenik AJ) 1259-1305.

Güler M 2007. Gebelik fizyolojisi. (Evcil Hayvanlarda Doğum ve İnfertilite. TR: Medisan: Ed. Alaçam E) 99-108.

Haliloğlu S, Serpek B 2000. The effects of plasma vitamin $\mathrm{c}$ and ceruloplasmin levels and exogenous vitamin c supplementation on reproduction in sheep. Turk J Vet Anim Sci 24: 403-411.

Johnson SK, Sailey RA, Inskeep EK, Lewis PE 1996. Effect of peripheral concentrations of progesterone on follicular growth and fertility in ewes. Domest Anim Endocrin 13: 69-79.

Karagül H, Sallmann HP, Fidanci UR, Sel T, Çelik S, Vural R, Önal A, Ünal N 1999. The effect of vitamin $\mathrm{E}$ and selenium deficiency on the reproductive hormones and antioxidative systems in akkaraman Sheep. Proceedings of Deutsch-Türkische Agrarforschug-6. Symposium, 383-388 Giessen, Germany.

Mitchell LM, King ME, Aitken RP, Gebbie FE, Wallace JM 1999. Ovulation, fertilization and lambing rates, and peripheral progesterone concentrations, in ewes inseminated at a natural oestrus during November or February. J Reprod Fertil 115: 133140.

Özarslan B 2014. Investigation of reproduction traits in bafra sheep breeding. Ankara University, Graduate School of Health Science, PhD, Ankara, Turkey.

Seekallu SV, Toosi BM, Duggavathi R, Barrett DMW, Davies KL, Waldner C, Rawlings NC 2010. Ovarian antral follicular dynamics in sheep revisited: comparison among oestrous cycles with three or four follicular waves. Theriogenology 73: 670-680.

Sulu N, Özsar S, Güven B 1988. Determination of progesterone levels in blood sera in Sakız sheep by use of EIA. Vet J Ankara Univ 35: 209-217.

Tekerli M, Gündoğan M, Akinci Z, Akcan A 2002. Determination of production characteristics of Akkaraman, Daglic, Chios and Awassi sheep in the conditions of Afyon Province I. Fertility and survival rate. Lalahan Hay. Araşt. Enst. Derg. 42: 29-36.

Tworoger SS, Hankinson SE 2006. Collection, processing and storage of biological samples in epidemiologic studies: sex hormones, carotenoids, inflammatory markers and proteomics as examples. Cancer Epidemiol. Biomarkers Prev. 15: 1578-1581.

Ünal N, Akçapinar H. Behavior in sheep 1994. Bahri Dağdaş Hay. Araşt. Derg. 4: 113-123.

Ünal N, Atasoy F, Akçapinar H, Erdoğan M 2003. Fertility traits, survival rate and growth characteristics of Karayaka and Bafra (Chios x Karayaka $\mathrm{B}_{1}$ ) Genotypes. Turk J Vet Anim Sci 27: 265-272.

Ünal N, Akçapinar H, Atasoy F, Koçak S, Aytaç M 2004. The body weight and fleece traits of White Karaman, Chios x White Karaman $\mathrm{F}_{1}$, $\mathrm{B}_{1}$, Kivircık $\mathrm{x}$ White Karaman $\mathrm{F}_{1}, \mathrm{~B}_{1}$, Karayaka and Bafra Sheep. Lalahan Hay. Araşt. Enst. Derg. 44: 15-22.

Ünal N, Aytaç M, Koçak S, Erol H 2006a. Some of the reproduction characteristics in various local pure and crossbred sheep genotypes. Lalahan Hay. Araşt. Enst. Derg. 46: 45-57.

Ünal N, Akçapinar H, Atasoy F, Aytaç M 2006b. Some reproductive and growth traits of crossbred genotypes produced by crossing local sheep breeds of kivircik $\mathrm{x}$ white karaman and chios $\mathrm{x}$ white karaman in steppe conditions. Archiv Tierzucht 49: 55-63.

Yakan A, Unnal N, Dalci MT 2012. Reproductive traits, growth and survival rates of akkaraman, awassi and kivircik sheep breeds in Ankara conditions. Lalahan Hay. Araşt. Enst. Derg. 52: 1-10. 